Brain, Behavior and Evolution

Editor-in-Chief: R. Glenn Northcutt, La Jolla, Calif.

\section{Reprint}

Publisher: S.Karger AG, Basel

Printed in Switzerland
NASA-CR-204576

$$
\begin{gathered}
\text { NAG }-7897 \\
1 N-51-612
\end{gathered}
$$

Brain Behav Evol 1995;46:131-140

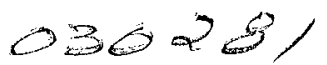

Arthur N Popper

Peggy L Edds Walton

Department of Zoology,

University of Maryland,

College Park, Md., USA

\title{
Structural Diversity in the Inner Ear of Teleost Fishes: Implications for Connections to the Mauthner Cell
}

unst

\section{Key Words}

Audition

Hearing

Hair cell

Saccule

Lagena

Utricle

Eighth nerve

\section{Abstract}

A body of literature suggests that the Mauthner cell startle response can be elicited by stimulation of the ear. While we know that there are projections to the $\mathrm{M}$-cell from the ear, the specific endorgan(s) of the ear projecting to the M-cell are not known. Moreover, there are many reasons to question whether there is one pattern of inner ear to $\mathrm{M}$-cell connection or whether the endorgan(s) projection to the $\mathrm{M}$-cell varies in species that have different hearing capabilities of hearing structures. In this paper, we briefly review the structure of fish ears, with an emphasis on structural regionalization within the ear. We also review the central projections of the ear, along with a discussion of the limited data on projections to the M-cell.

\section{Introduction}

A substantial body of literature suggests that there are interactions between the inner ear and the Mauthner cell (M-cell) of fishes [e.g., Moulton and Dixon, 1967; Zottoli, 1977; Eaton et al., 1991]. These data demonstrate that the classic M-cell startle response can be elicited by acoustic stimuli [Zottoli, 1977; Canfield and Eaton, 1990; Eaton and Emberley, 1991], although the specific nature of the stimulus (e.g., pressure vs. displacement, frequency) needed to elicit this response is not clear. Moreover, there is evidence to suggest that the $\mathrm{M}$-cell can be stimulated by the lateral line [e.g., McCormick, 1983; Zottoli and van Horne, 1983] and visual stimuli [e.g., Eaton et al., 1977; Zottoli, 1976].

Many questions about the relationship between the inner ear and M-cell are still open. For example, while we know that there are projections to the $\mathrm{M}$-cell from the ear [Lin et al., 1983; Bleckmann et al., 1991], we will argue below that the specific endorgan(s) of the ear projecting to the M-cell are not known. Moreover, based upon new knowledge of the inner ear [reviewed in Popper and Fay, 1993], there are many reasons to question whether there is one pattern of inner ear to M-cell connection or whether the endorgan(s) projecting to the $\mathrm{M}$-cell varies in species that have different hearing capabilities or different auditory structures. We think it is important to argue, though we will not do so directly in this paper [but see Eaton and Popper, 1995], that there are still numerous questions to be asked about the morphological and physiological relationship between the whole octavolateralis system and the M-cell. Until these questions are answered it will not be possible to completely understand the interaction(s) of these two systems. vur: 
Substantial progress has been made in our understanding of the structure and function of the auditory system in teleosts since the earliest studies of the relationship of the M-cell and inner ear [e.g., Bartelmez, 1915; Bodian, 1937]. As a consequence, it is necessary to reexamine what is known about the interactions of the two systems. In fact, data on the function of the ear may help us to better understand the relationship between the ear and the M-cell. While it is likely that the M-cell is stimulated by otolithic endorgans of the ear (see below), the endorgan primarily responsible for stimulation is still not clear. In addition, recent data on the structure and function of the ear suggest that each of the endorgans is multifunctional and that "the ears' of fishes are far more complex structurally than previously thought. Consequently, it is possible that different ear regions subserve different functions (even modalities) and that the M-cell is affected by small, and possibly specialized, regions of the ear. As will be discussed below, neuroanatomical and physiological studies of M-cell afferents from the ear tend to support this argument.

The thrust of this paper is two-fold. First, we will briefly review the structure of fish ears, with an emphasis on structural regionalization within the ear. Second, we will review the central projections of the ear, along with a discussion of the limited data on projections to the M-cell.

\section{Heterogeneity of the Otic Endorgans}

Before starting this discussion we want to make a critical point regarding the diversity in structure found among ears of different species of bony fishes [e.g., Retzius, 1881]. While we do not know the functional significance of this diversity, we have argued that there is no such thing as 'the' fish ear [Platt and Popper, 1981; also see Schellart and Popper, 1992; Popper and Fay, 1993; Popper and Platt, 1993], since it is highly likely that the variation in ear structure also represents diversity in ear function. In particular, there are substantial inter-specific differences in hearing capabilities and in structure of the ear (and possibly in the central nervous system [CNS] anatomy) when comparing hearing 'specialists' and hearing 'nonspecialists'. Hearing nonspecialists are those species that have a relatively narrow range of hearing (e.g., $50 \mathrm{~Hz}$ to $500 \mathrm{~Hz}$ ), while hearing specialists can generally detect sounds to over $1,000 \mathrm{~Hz}$ [reviewed in Schellart and Popper, 1992]. Specialists have special structures that appear to enhance hearing capabilities. Such structures include the Weberian ossicles of otophysan fishes, which connect the swimbladder to the inner ear, or rostral projections of the swimbladder, which terminate close to one of the otic endorgans of the ear, as in clupeids and some holocentrids [reviewed in Popper and Coombs, 1982; Popper and Platt, 1993]. Thus, we must be very cautious with generalizations regarding the structure of the ear and even with how ears in various species may interact with the M-cell.

\section{General Structure of the Ear}

Recent reviews have provided overviews of the structure and function of the auditory system of fishes, including the ear and its innervation [e.g., McCormick, 1992; Schellart and Popper, 1992; Popper and Platt, 1993], so we will not cover this topic in any detail. However, it is important to have some overall understanding of the basic structure of the ear before dealing with details of organization.

The ear in fishes has three semicircular canals and three otolithic endorgans, the saccule, lagena and utricle. Many species of fish have a seventh endorgan, the macula neglecta, but this tends to be very small and has an unknown function. There is substantial inter-specific variability in the gross structure of fish ears [see Retzius, 1881, for an historic description of ears of a wide range of vertebrate species, including fish].

The most substantial variability is associated with the otolithic endorgans, and particularly those believed to be involved in audition, generally (but not always) the saccule and lagena [Platt and Popper, 1981; Popper and Coombs, 1982]. The structure of the utricle tends to be very conservative among most species [e.g., Platt, 1983]. However, in those species where the utricle most clearly appears to be involved with audition, such as in clupeids and ariid catfish, the utricular structure is very complex and different from species in which the auditory role of the endorgan is thought to be less prominent [e.g., Blaxter et al., 1981; Popper and Tavolga, 1981].

Each of the otolithic endorgans in most bony fishes has a single dense calcareous otolith. The sensory epithelium (or macula) and otolith are connected by a thin, gelatinous, otolithic membrane [e.g., Dunkelberger et al., 1980]. The epithelium contains sensory hair cells with an apically located ciliary bundle. The magnitude of the hair cell response depends upon the direction of shearing of the ciliary bundle [Flock, 1971; Hudspeth, 1985]. This shearing occurs in fishes when the very dense otolith moves at a different amplitude and phase than the sensory epithelium during acoustic or vestibular stimulation of the ear [reviewed in Popper and Fay, 1993].

Studies of the ears of several fish species, most notably the goldfish Carassius auratus, and the oscar Astronotus ocellatus, have shown that there is considerable heteroge- 
neity in many aspects of the structure of individual endorgans of the ear. In other words, rather than each epithelium being uniform along its length in hair cell structure, physiology, and distribution of hair cells with similar apical morphologies, there is structural regionalization within an epithelium. This has led us to propose that there is also functional regionalization within the epithelium [see Popper et al., 1982; Platt and Popper, 1984]. In such a system, some regions would respond to one type of signal (e.g., different frequency and/or modality), and other regions would respond to another type of signal.

\section{Evidence for Heterogeneity}

The argument for heterogeneity is based upon (a) gross structure of the ear, (b) lengths of ciliary bundle on hair cells in different epithelial regions, (c) biochemistry and morphophysiology of different hair cells, (d) ultrastructure of hair cells in different regions, and (e) physiology of these hair cells. Additional evidence comes from the patterns of innervation of the saccular and utricular epithelia by both afferent and efferent neurons.

\section{Gross Structure of the Ear}

Several facets of gross structure suggest heterogeneity in the ear. Most importantly, the shapes of the sensory epithelia are not uniform along their length, and portions of the epithelium may not lie directly under the otolith. An interesting example of this is found in several of the deep sea myctophids (lantern fish) in which the otolith lies over the caudal half of the saccular epithelium, while the rostral half of the epithelium is only covered by the otolithic membrane [Popper, 1977]. Similarly, the otolithic membrane is very thick over certain regions of the lagenar epithelium in goldfish [Platt, 1977] and over the entire utricular epithelium in most species [Platt and Popper, 1981]. While the functional significance of these observations is not clear, the differences are likely to affect the way(s) in which sensory hair cells are stimulated during relative movement between the otolith and the sensory epithelium [reviewed in Schellart and Popper, 1992].

\section{Ciliary Bundle Length and Distribution}

Each ciliary bundle on a sensory hair cell consists of a single true cilium, the kinocilium, and 40 or more microvillus-like stereocilia. The kinocilium is longer than the stereocilia, and the whole bundle may vary in length, depending upon the location of the hair cell on the epithelium [e.g., Dale, 1976; Platt, 1977; Popper, 1977; Platt and Popper, 1981, 1984; Wegner, 1982]. For example, the ciliary bundles on the hair cells are graded in length along the saccule in otophysan fishes (e.g., goldfish, catfish), with the shortest being at the rostral end and the longest at the caudal [Platt, 1977; Platt and Popper, 1984]. In many fishes other than otophysans (e.g., Astronotus, Opsanus), the ciliary bundles in the central region of the saccular epithelium tend to be shorter than those at the margins [e.g., Popper, 1977; Platt and Popper, 1984].

The functional significance of the different ciliary bundle lengths is not clear, although it has been suggested that length may be correlated with frequency response characteristics of the hair cells in reptiles and birds [e.g., Frishkopf and DeRosier, 1983; Saunders and Dear, 1983]. In these species, shorter bundles tend to be associated with detection of higher frequencies than long bundles, and the longest bundles are found in the cristae of the semicircular canals, which detect very low frequency vestibular stimuli [reviewed in Platt, 1983]. While a similar correlation has yet to be made for any fish species, studies with the goldfish, Carassius auratus [Furukawa and Ishii, 1967], and a catfish, Ictalurus nebulosus [Moeng and Popper, 1984], suggest that the rostral end of the saccular epithelium (with short bundles) responds to higher frequencies than the caudal end of the epithelium (long bundles).

If the $M$-cell receives neurons from only a restricted epithelial region of a 'tonotopically' organized saccule (e.g., goldfish and other otophysans), the auditory input to the M-cell may have a limited frequency range. However, if the M-cell input is from across the whole epithelium, then it would comprise a broader range of frequencies. Importantly, it is possible that different acoustic stimuli excite the $\mathrm{M}$-cell in hearing specialists and nonspecialists.

\section{Biochemistry and Morphophysiology}

Our studies of utricular hair cells in Astronotus have demonstrated that there are at least two distinct populations of cells. Studies using an antibody to a calcium-binding protein, S-100, have shown that cells in one epithelial region, the striola, have the antigen, but that cells in other regions (extrastriola) do not [Saidel et al., 1990a]. Investigations have also shown that striolar hair cells have substantially greater sensitivity than do extratriolar hair cells to gentamicin sulphate, an ototoxic aminoglycoside antibiotic [Yan et al., 1991].

Finally, studies of neuractive sites in eighth nerve fibers support the findings determined with an S-100 antibody and gentamicin. The site of spike initiation is directly adjacent to striolar hair cells, while it is some distance from extrastriolar cells [Saidel et al., 1990b]. As a result, input from several extrastriolar hair cells may need to be combined or integrated in order to get a response in afferents from this epithelial region [Saidel et al., 1990b]. 
All three of these studies provide complementary results, indicating that there are striking differences between striolar and extrastriolar hair cells and in their innervation. The saccule of Astronotus shows differences in S-100 and spike initiating sites between central and marginal cells [Saidel et al., 1990a, b]. Moreover, cells at the rostral and caudal ends of the saccular epithelium of Carassius show differences in the presence of S-100, with the rostral cells being more reactive to the $\mathrm{S}-100$ antibody than the caudal cells [Saidel et al., 1990a]. Preliminary evidence indicates that the same cells that have the S-100 antigen in Carassius are also damaged by gentamicin [Platt and Yan, 1993].

\section{Innervation}

Although there have been only a limited number of studies, sufficient data are available to support the suggestion that there is intra-epithelial variation in innervation of sensory hair cells. Studies of the lagena in the anabantid Colisa show some differences in the extent of efferent innervation in the central hair cells compared to marginal hair cells [Wegner, 1982]. Similarly, hair cells in the central region of the saccule of Astronotus have significantly greater efferent innervation than marginal cells, and there is also some indication of differences in afferent innervation of hair cells in different regions of the saccule [Popper and Saidel, 1990].

Analyses of arbor size have demonstrated central versus peripheral differences in the extent of the saccular epithelium covered by an individual neuron in Astronotus [Presson et al., 1992] and in rostral versus caudal regions of the saccule of Carassius [Sento and Furukawa, 1987; Edds et al., 1989; Edds and Popper, 1990]. Axon diameter is greater in the striolar region of the utricle and in the central region of the saccule in Astronotus [Saidel et al., 1990a; Presson et al., 1992]. Large diameter fibers originating in these regions may be those identified as projecting to the lateral dendrite of the M-cell. Studies of projections from the ear to the $\mathrm{M}$-cell demonstrate that the eighth nerve fibers to the lateral dendrite are large diameter [Lin et al., 1983; Bleckmann et al., 1991] with high conduction velocities. We suggest that the saccule may not be the only otolithic endorgan providing large diameter afferents to the M-cell. The lagena and the utricle may also provide input [e.g., McCormick, 1983], depending upon the species and the functional divisions of the ear. For the most part, let us consider the goldfish.

Although some studies have indicated that the largest diameter axons innervate only the rostral saccule of goldfish [Furukawa, 1966; Furukawa and Ishii, 1967; Sento and Furukawa, 1987], there is other evidence that large diam- eter fibers may be spread along the length of the saccule. Using cobaltous-lysine to label 118 saccular afferents, Edds et al. [1989] found that the largest axons $(4-6 \mu \mathrm{m})$ were not restricted to any portion of the saccule. If the saccule is organized tonotopically along its length, as has been suggested by the work of Furukawa and Ishii [1967] based on physiological recordings from eighth nerve fibers, one might predict that large diameter axons would be present along the tonotopic axis and not be restricted to the higher frequency end of the saccule.

Some large diameter axons also leave the lagena and the utricle of goldfish [P.L. Edds-Walton, unpublished observation]. Edds and Popper [1990] found that the range of axon diameters from the lagenar macula exceeds those from the saccular macula. Also, large diameter fibers originate in the striolar region of the utricle of Astronotus [Saidel et al., 1990a]. Saidel et al. [1990a] showed that spike initiating regions lie in close apposition to the hair cells in the striola, which could minimize integration time for input to the afferent fibers and provide rapid input to the $\mathrm{M}$-cell from the utricle. Clearly, more work is required to determine the origins of the large diameter fibers that innervate the M-cell in both otophysines and non-otophysines.

\section{Hair Cell Ultrastructure}

Investigations using transmission electron microscopy revealed significant ultrastructural differences between striolar and extrastriolar hair cells in the utricle of Astronotus [Chang et al., 1992]. The cells in the striolar region are larger and have much more extensive afferent and efferent innervation (as determined by number of synapses) than extrastriolar cells.

Striolar cells also have a number of organelles that are distinctly different from those in extrastriolar hair cells [Chang et al., 1992]. Based upon ultrastructural differences and upon comparisons with hair cells found in amniote vestibular endorgans [Wersäll, 1960], it was concluded that Astronotus (and most likely other species of teleosts) have at least two ultrastructurally distinct hair cell types. Extrastriolar hair cells are very similar to amniote type II hair cells [Wersäll, 1960]. While it has been argued that amniote type I cells are not present in fishes [Wersäll, 1960], the striolar cells are strikingly similar to those cells, and they have, accordingly, been called 'type I-like' [Chang et al., 1992]. Sensory hair cell types similar to those found in the utricle are also found in the saccule of Astronotus [Popper et al., 1993]. It has been suggested that several types of hair cells are also present in the lagena of this species [Chang et al., 1992] as well as in the saccule of the goldfish [Saidel et al., 1995]. 
Clearly, piscine hair cells differ in ultrastructure and in responses to $S-100$ and gentamicin. While there are no physiologcal data to correlate with the ultrastructure and biochemistry in Astronotus, it has been suggested that there are important functional differences in different types of hair cells in the vestibular system of mammals [Correia and Long, 1990], and it is reasonable to speculate that functional differences are also present in the various types of hair cells in fishes.

\section{Hair Cell Physiology}

Patch-clamp studies of isolated hair cells from the saccule in Carassius [Sugihara and Furukawa, 1989] and Opsanus [Steinacker and Romero, 1992] demonstrate that there are distinct populations of hair cells with regard to calcium and potassium currents. Moreover, Sugihara and Furukawa [1980] were able to correlate ionic channel differences with differences in shapes of disassociated cells from various saccular regions. While it is critical to attempt to correlate these differences with ultrastructural differences in each species, these data do add support to the argument that there are multiple hair cell types in the ears of not only Astronotus but also Carassius and Opsanus.

\section{Summary of Heterogeneity}

Recently accumulated evidence, as cited above, shows that there is substantial intra- and inter-epithelial variation in structure and physiology in otolithic endorgans of fish. While these results have not yet been correlated with physiological findings on signal processing, it is parsimonious to argue that the heterogeneity is probably correlated with functional variability. While the bearing on M-cell function is not at all certain, we suggest that it is possible that only certain ear regions provide appropriate input to excite the M-cell. Thus, it will only be after detailed analysis of the relationship between the ear and $\mathrm{M}$-cell that we will understand the way that the two systems interact.

\section{Central Projections of the Eighth Nerve}

Central projections of the eighth cranial nerve in fishes are complex, and the data are still very limited in several ways. First, data are only available for a few species, and these species are not necessarily representative of the broad range of fish taxa. Second, many of the species studied are electrosensory: differences in the nuclei of the CNS in electrosensory versus non-electrosensory species [see McCormick, 1992] complicate understanding of the central projections of the ear alone. Third, while there is a good body of data on overall eighth nerve projections, there are far fewer data on projections from individual otic endorgans and virtually no data on central projections from individual regions of endorgans, such as the striolar versus extrastriolar region of the utricle or the rostral versus caudal regions of the saccule.

Finally, there are almost no data on the projections from the ear to the M-cell. Specific experimental data on projections from the ear to M-cell are primarily for Carassius [Bartelmez, 1915; Bartelmez and Hoerr, 1933; Bodian, 1937; Lin et al., 1983]. Less extensive data are available for a few other species, but such data have not been obtained in studies directly investigating innervation of the M-cell.

\section{Projections from Otic Endorgans to the CNS}

The descriptions given below are generalized and do not reflect species that have electrosensory specializations. The inner ear endorgans project to four or five nuclei in the medulla, depending upon the species studied. These nuclei extend rostro-caudally from approximately the level of the caudal lobe of the cerebellum to a region caudal to the vagal lobes (fig. 1). The bulk of the data on bony fishes comes from descriptions of the sites of termination for octaval afferents for a very small number of species [reviewed in McCormick, 1992].

Three of the nuclei receiving octaval input are present at, or adjacent to, the entrance of the eighth nerve (fig. $2 b, c$ ). The largest of these, the descending nucleus, is somewhat triangular in shape, with the more dorsal region extending medially. Just rostral to the main body of the descending nucleus is the magnocellular nucleus. In teleosts, the tangential nucleus lies ventral and lateral to the magnocellular nucleus. Rostral to the entrance of the eighth cranial nerve is the anterior nucleus (fig. $2 \mathrm{a}$ ), and the most caudal nucleus in the octaval column is the posterior nucleus (fig. $2 \mathrm{~d}$ ).

The medullary nuclei do not receive identical input from the otolithic endorgans and the semicircular canal cristae. The anterior octaval nucleus receives input from the three canal cristae and the three otolithic endorgans. An auditory function has been ascribed to this nucleus, due to the presence of afferents ascending to the auditory portion of the midbrain (the medial torus semicircularis) in Cyprinus [Echteler, 1984, 1985] and Gillichthys [Northcutt, 1980]. However, Purkinje cell afferents from the cerebellum heavily innervate the most rostral region of the anterior nucleus in Carassius [Edds et al., 1992], where canal cristae afferents predominate [C.A. McCormick, pers. com- 


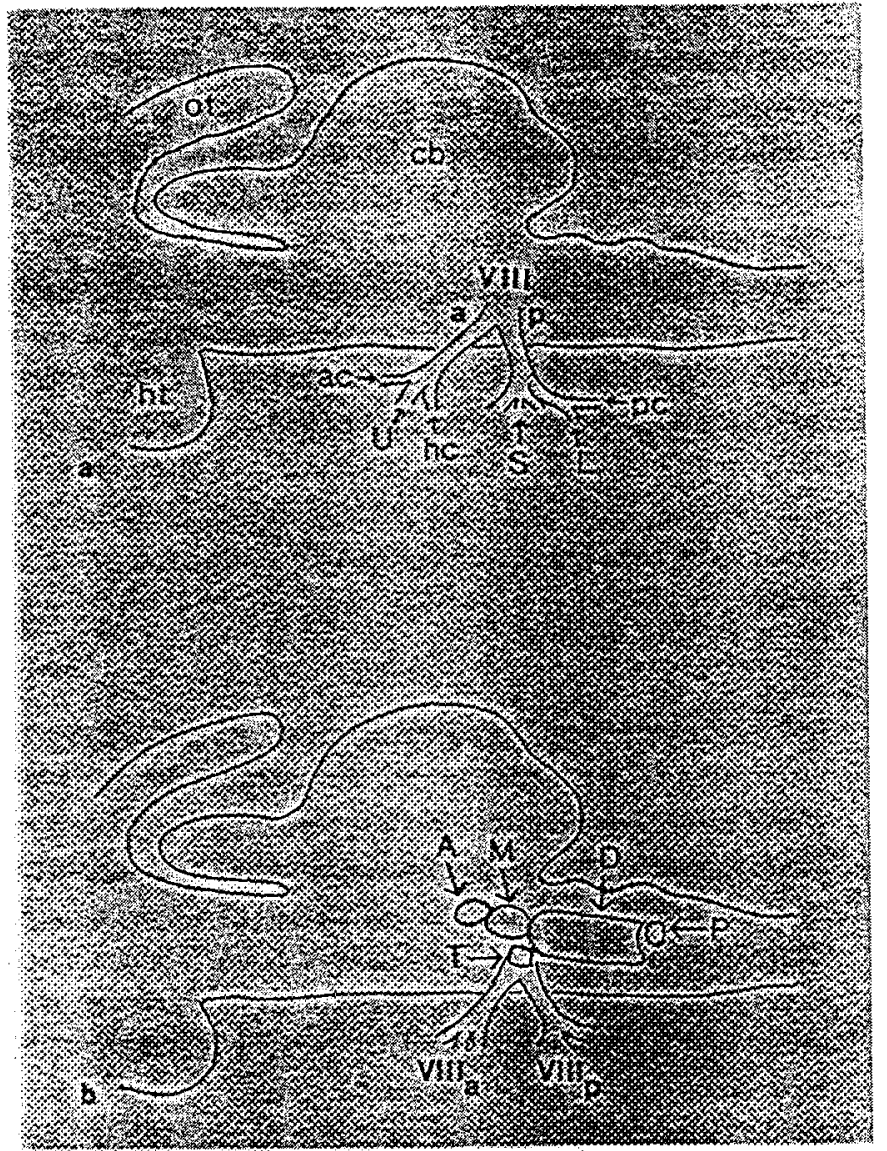

Fig. 1. a Outlines of a sagittal section through the brain of a teleost fish. The eighth nerve (VIII) consists of two major branches the anterior (a) and posterior ( $p$ ). Smaller branches from each carry fibers to/from the otolithic endorgans ( $L=$ lagena; $S=$ saccule; $U=$ utricle) and the semicircular canal cristae ( $\mathrm{ac}=$ anterior canal; $\mathrm{hc}=$ horizontal canal; $p c=$ posterior canal). (Other abbreviations: $c b=$ cerebellum; $\mathrm{ht}=$ hypothalamus; ot = optic tectum.) $\mathbf{b}$ Generalized location of the octaval nuclei in the medulla of teleost fishes. The shapes and relative sizes of the nuclei vary with species. (Abbreviations: VIII $=$ Anterior eighth nerve; VIII $=$ posterior eighth nerve; $A=$ anterior; $D=$ descending; $M=$ magnocellular; $P=$ posterior; $T=$ tangential) [modified from Schnitzlein and Faucette, 1969].

mun.]. Therefore, there may be vestibular and auditory regions in the anterior nucleus, at least in this species.

The magnocellular nucleus is variable in size in different species and may have functional subdivisions (fig. 2b). It receives input from all of the octaval nerves and, in the majority of species examined to date, some input from the lateral line nerves [Highstein et al., 1992; McCormick, 1992]. Therefore, it seems likely that the magnocellular nucleus, with its very large cells, is an integration center for inner ear and lateral line input in some species.
The tangential nucleus occurs with the magnocellular nucleus rostrally, and its caudal extent overlaps with the most rostral portions of the descending nucleus. The tangential nucleus is unique among the octaval nuclei in that it receives extensive input only from the semicircular canal cristae and, in somespecies, the utricle. For this reason the tangential nucleus is probably a vestibular processing area. Data from a Purkinje cell projection study further support this idea, in that the tangential nucleus receives substantial input from the cerebellum in Carassius [Edds et al., 1992].

The descending nucleus appears to have a dorsal-ventral organization that is most apparent in the more rostral portion of this nucleus (fig. 2c) [McCormick, 1992, pers. commun.]. The dorsal area of the nucleus is primarily innervated by saccular and lagenar afferents, with some overlap of utricular afferents; the lateral and ventrolateral areas are innervated by utricular and canal afferents [e.g., McCormick, 1981, 1992]. The preponderance of canal cristae afferents in the more ventral areas may be indicative of a different functional organization for the dorsal versus ventral descending nucleus. An auditory function has been implied for the dorsomedial portion of this nucleus, based on direct or indirect projections to the auditory midbrain [Echteler, 1984; Bleckmann et al., 1991; McCormick, 1992]. A vestibular function is indicated by the lack of projections to the auditory midbrain and the presence of Purkinje cell afferents from the cerebellum to the more lateral and ventral regions of the descending nucleus of Carassius, where canal cristae afferents occur [Edds et al., 1992].

The posterior nucleus lies just caudal of the lateroventral portion of the descending nucleus (fig. $2 \mathrm{~d}$ ). Projections to the nucleus are rarely described due to the vagaries of dye transport along the entire extent of the octaval column in the medulla. In studies that have reported input to this nucleus [e.g., Meredith and Butler, 1983], no subnuclear organization has been discerned. All afferents appear to mix, with no regions where otolithic or canal cristae have exclusive input.

Two variations on the organization of the octaval nuclei in fishes are worthy of mention. The holostean Amia calva (bowfin) has only four octaval nuclei: anterior, magnocellular, descending, and posterior [McCormick, 1981]. Since the four octaval nuclei are organized similarly to those of teleosts, McCormick has suggested that four octaval nuclei is the primitive state. Northcutt [1980] has suggested that the tangential nucleus resulted from an evolutionary division of the magnocellular into dorsomedial and ventrolateral components.

The other interesting variation occurs in the herring Clupea harengus [Meredith, 1985]. In this and other clupeids, 
Fig. 2. Transverse sections rostral to caudal $(\mathbf{a}-\mathbf{d})$ through the brain of a generalized non-electroreceptive teleost fish to illustrate the relative locations of the octaval nuclei and the Mauthner cell (m). The rostrocaudal extent of the octaval nuclei in the medulla and the degree of overlap of otolithic endorgan and canal cristae terminations vary with species. Shading represents subnuclear organizations based on octaval terminations observed in several species. PON is unshaded, since no subnuclear organization has been described. The black regions represent primarily saccular and lagenar input, but their terminations overlap with those of the utricle in the most heavily shaded area. Canal cristae afferents tend to terminate in the more ventral regions of the octaval nuclei, but there are species variations. The dorsomedial extension (dashed lines) of the descending nucleus (in ' $c$ ') may be present only in hearing specialists. (Abbreviations: $\mathrm{VII}_{3}=$ Anterior branch of acoustic nerve; $\mathrm{VIII}_{\mathrm{p}}=$ posterior branch of acoustic nerve; $V_{d}=$ descending trigeminal nerve; $X=$ vagal nerve entrance; $A O N=$ anterior octaval nucleus; $c=$ caudalis nucleus; $C=$ canal cristae; $c b=$ cerebellum; $D O N=$ descending octaval nucleus; $\mathrm{e}=$ efferent nuclei; $\mathrm{L}=$ lagena; $\mathrm{LL}_{\mathrm{a}}=$ anterior lateral line nerve; $\mathrm{LL}_{\mathrm{p}}=$ posterior lateral line nerve; $\mathrm{m}=$ Mauthner cell; $\mathrm{MAG}=$ magnocellular octaval nucleus; $\mathrm{med}=$ medialis nucleus; $\mathrm{ml}=$ molecular layer of medialis; $\mathrm{mlf}=\mathrm{me}$ dial longitudinal fasciculus; $\mathrm{PON}=$ posterior octaval nucleus; if $=$ reticular formation; $\mathrm{S}=$ saccule; $\mathrm{TON}=$ tangential octaval nucleus; $U$ = utricle; $\mathrm{vl}=$ vagal lobe) [modified from Meredith and Butler, 1983, and McCormick, 1992].

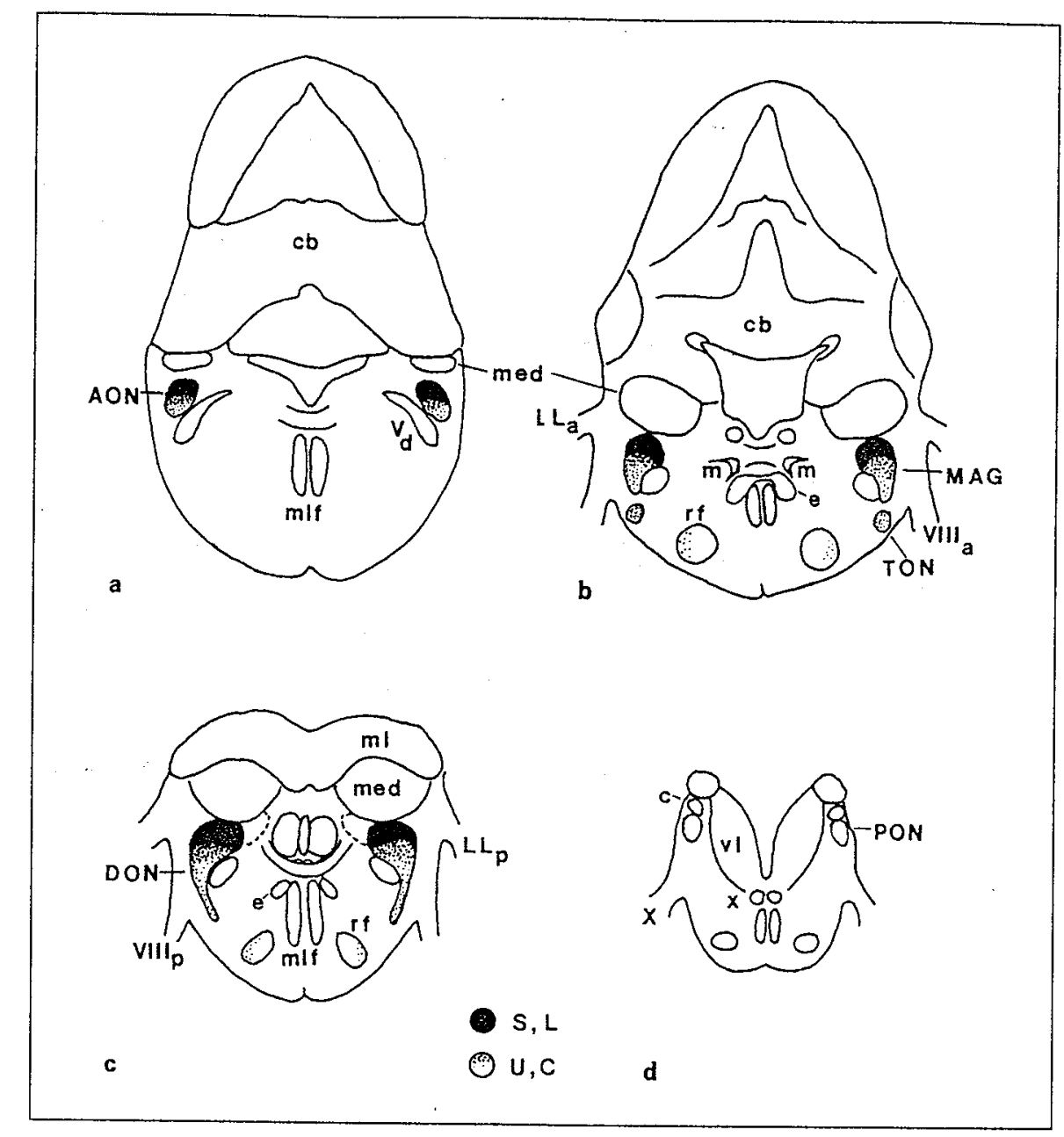

hearing is associated with subdivisions of the utricle. Meredith found that afferents from two subdivisions of the utricle project to dorsomedial locations in the anterior and descending nuclei, where saccular afferents are found in other teleosts. This is worthy of note, since the peripheral differences in endorgan function are reflected in different termination sites for those endorgans. Therefore, the requirements of the CNS for appropriate processing of a sensory modality seem to have dictated the organization of the afferents. Further, Meredith's findings provide additional evidence for auditory function in the anterior and descending nuclei.

In summary, the inner ear endorgans of teleost fishes project to five medullary nuclei. None of the octaval nuclei appear to be entirely auditory; rather, all of them appear to have either vestibular function or a vestibular subdivision, based on their projections. Physiological data are needed to test this hypothesis.

\section{Projections of the Eighth Nerve to the Mauthner Cell}

It is not yet clear which endorgan(s) of the ear actually send projections to the $\mathrm{M}$-cell.

In fact, most of the studies labeling individual branches of the eighth nerve have not reported innervation of the Mauthner cell. There may be two reasons for this. First, the investigators may not have been looking for innervation of the Mauthner cell. Second, the labeling technique may not have revealed the endings on the dendrites of the Mauthner 
cell. This was the case when Zottoli and van Horne [1983] labeled the posterior lateral line (PLL) nerve with horseradish peroxidase (HRP). No endings were apparent on the Mauthner cell lateral dendrite or soma, in spite of physiological evidence that PLL nerve stimulation was detectable at the proximal portion of the lateral dendrite and the soma. The authors concluded that the PLL input is likely to be via interneurons, and only a transneuronal dye would reveal the sites of input from the posterior lateral line.

Direct input from saccular afferents has been assumed since the early work of Bartelmez [1915] and Bartelmez and Hoerr [1933]. These investigators reported that they had traced saccular fibers from the distal lateral dendrite of the $\mathrm{M}$-cell to the saccular epithelium in Carassius, using a Cajal preparation [uncited; probably a Golgi preparation, per C.E. Carr, pers. commun.]. The importance of the saccular portion of the eighth nerve was further reinforced by observations that an auditory stimulus was sufficient to evoke the startle response [Zottoli, 1977; Canfield and Eaton, 1990; Eaton and Emberley, 1991] and the assumption that the saccule is the auditory endorgan in fish [e.g., von Firisch, 1938].

Virtually all studies to date that have suggested the saccule as the source of fibers actually have traced fibers lying in the 'posterior branch' of the eighth nerve. Since the posterior branch innervates saccule, lagena, posterior crista and (often) the macula neglecta (fig. 1a), it is reasonable to speculate that the fibers projecting to the $\mathrm{M}$-cell could have arisen not on the saccule but on one of the other endorgans. In Carassius (and other otophysans) in particular, lagenar and saccular afferents adjoin above the sensory epithelia, making the distinction of their origin at the brainstem a challenge worthy of Ludwig Mauthner or Gustav Retzius!

Several more recent tract-tracing studies have indicated specific endorgans as the origin of afferents to the Mauthner cell. Szabo et al. [1978] and Bell [1981] described the termination of large diameter saccular fibers on the lateral dendrite of the M-cell in the mormyrid Gnathonemus petersii. Bleckmann et al. [1991], using HRP, showed that the posterior branch of the eighth nerve projects to the Mauthner cell in a bottom-dwelling catfish, Ancistrus sp. They did not determine the endorgan of origin for the fibers, but their figure shows the dorsal portion of the projections continuing to the Mauthner cell. Again, since the posterior portion of the eighth nerve innervates both the saccule and the lagena, either or both of these endorgans could be the source of M-cell input in Ancistrus.

In addition to these studies on fishes with inner ear specializations, there have been several studies on nonspecialist species. Meredith and Butler [1983] reported sparse sac- cular and utricular projections to the distal and proximal regions, respectively, of the M-cell lateral dendrite in Astronotus. These results lead to the suggestion that the utricle, as well as the saccule, might project to the M-cell in other species.

Similar suggestions come from the work of McCormick [1983] on another cichlid, Crenicichla lepidota. McCormick demonstrated M-cell input in this species from both anterior and posterior rami of the eighth nerve, using degeneration studies. Since only the utricle and two canal cristae are innervated by the anterior ramus (fig. 1a), these results strongly support the argument that the projections to the M-cell arise, at least in part, from the utricle. Utricular projections to the M-cell were also found in a clupeid [Meredith, 1985]. Projections to the M-cell were seen only from fibers labeled at the middle region of the utricular epithelium, the region believed to have both vestibular and auditory functions [Meredith, 1985].

The utricle has also been implicated in excitation of the Mauthner cell based upon physiological studies in Carassius [Zottoli and Faber, 1979] and winter flounder, Pseudopleuronectes americanus [Zottoli, 1981]. In Carassius, subthreshold stimulation of the anterior branch of the eighth nerve caused a small post-synaptic potential in the M-cell. However, in combination with subthreshold input to the posterior branch of the eighth nerve (fig. 1b), stimulation of the anterior branch was sufficient to reach threshold. In the winter flounder, stimulation via the saccular branch or utricular branches of the eighth nerve resulted in similar excitatory potentials; however, it was unclear whether the utricular input alone was sufficient to reach threshold.

Input to the $\mathrm{M}$-cell from the lagena has also been suggested in studies of Carassius. Fay and Olsho [1979] have shown that the lagena responds to sound stimulation; consequently, we cannot exclude the potential role of lagenar input to the Mauthner cell. This suggestion is supported by our findings [Edds and Popper, 1990] that many of the afferent fibers from the lagena in goldfish have diameters as large as those from the saccule. Since large axon diameter is frequently described as a characteristic of input to the M-cell [e.g., Lin et al., 1983; Bleckmann et al., 1991], the source of those axons could be the lagena or the saccule.

Although a Mauthner cell had not been reported to be present in eels previously [Zottoli, 1978], Meredith and her colleagues [Meredith et al., 1987] suggested that the European eel, Anguilla anguilla, has a potential 'cell M'. Meredith et al. [1978] found utricular projections to a lateral dendrite of cell $\mathrm{M}$ and lagenar and crista afferents 'close to the soma' of cell $\mathrm{M}$. Interestingly, no lateral line afferents were found associated with cell $\mathrm{M}$. 
While the results summarized here certainly do not rule out the saccule as $a$ source of input to the M-cell in several species, the results also argue strongly for the potential involvement of the utricle and, possibly, the lagena, in M-cell input. Input to the M-cell may be from multiple endorgans in some species, or from different endorgans in different species. To this point, there has not been a complete investigation of potential projections to the $\mathrm{M}$-cell from individual otic endorgans in any species, so it is not possible to make any broad statements regarding inter-specific variation as yet.

\section{Summary and Conclusions}

In this paper we have reviewed evidence for substantial heterogeneity in the organization of the otic endorgans of several fish species. Also, we have shown that, despite years of investigation, the projections from the ear to the Mauthner cell are not well understood. While earlier stud- ies suggested that the saccule of Carassius projects to the M-cell, the evidence is neither strong nor exclusive for that endorgan. Clearly, the relationship between the ear (and lateral line) and the M-cell needs to be examined in far greater detail than has occurred in the past.

From our perspective, some of the most interesting questions to be answered involve which endorgans project to the M-cell, whether the M-cell is subserved by only subregions of epithelia, and the nature of the stimulus that will elicit the $\mathrm{M}$-cell response. In addition, it is not clear whether the structural and functional relationship between the octavolateralis system and the M-cell varies in species that differ in the organization of the ear and related peripheral structures.

\section{Acknowledgements}

Portions of the work reported here were supported by NIH grant DC-00140 from NIDCD, NASA grant NAG-2-787, ONR grant N00014-92-J-1 14 and NIMH predoctoral fellowship MH 10256.

\section{References}

Bartelmez, G.W. (1915) Mauthner's cell and the nucleus motorius tegmenti. J. Comp. Neurol., 25: $87-128$

Bartelmez, G.W., and N.L. Hoerr (1933) The vestibular club endings in Ameirurus. Further evidence of the morphology of the synapse. J. Comp. Neurol., 57: 401-428.

Bell, C. (1981) Central distribution of octavolateral afferents and efferents in a teleost (Mormyridae) J. Comp. Neurol., 195: $391-414$.

Blaxter, J.H.S., E.J. Denton, and J.A.B. Gray (1981) Acoustico-lateralis systems in clupeid fishes. In Hearing and Sound Communication in Fishes (ed. by W.N. Tavolga, A.N. Popper, and R.R. Fay), Springer, New York, pp. 39-59.

Bleckmann, H., U. Niemann, and B. Fritzsch (1991) Peripheral and central aspects of the acoustic and lateral line system of a bottom dwelling catfish, Ancistrus sp. J. Comp. Neurol., 314: 452-466.

Bodian, D. (1937) The structure of the vertebrate synapse. A study of the axon endings of the Mauthner's cell and neighboring centers in the goldfish. J. Comp. Neurol., 68: 117-159.

Canfield, J.G., and R.C. Eaton (1990) Swimbladder acoustic pressure transduction initiates Mauthner-mediated escape. Nature, 347: 760-762.

Chang, J.Y.S., A.N. Popper, and W.M. Saidel (1992) Heterogeneity of sensory hair cells in a fish ear. J. Comp. Neurol., 324: 621 -640 .
Correia, M.J., and D.G. Long (1990) An electrophysiological comparison of solitary type I and type II vestibular hair cells. Neurosci. Lett., 116: 106-111.

Dale, T. (1976) The labyrinthine mechanoreceptor organs of the cod Gadus morhua L. (Teleostei Gadidae). Norw. J. Zool, 24: 85-128.

Dunkelberger, D.G., J.M. Dean, and N. Watabe (1980) The ultrastructure of the otolithic membrane and otolith of juvenile mummichog. J. Morphol., 163: 367-377.

Eaton, R.C., R.A. Bombardieri, and D.L. Meyer (1977) The Mauthner-initiated startle response in teleost fish. J. Exp. Biol., 66:65-81.

Eaton, R.C., R. DiDomenico, and J. Nissanov (1991) Role of the Mauthner cell in sensorimotor integration by the brain stem escape network. Brain Behav. Evol., 37: 272 -285.

Eaton, R.C., and D.S. Emberley (1991) How stimulus direction determines the trajectory of the Mauthner-initiated escape response in a teleost fish. J. Exp. Biol., 161: 469-487.

Eaton, R.C., and A.N. Popper (1995) The octavolateralis system and Mauthner cell: interactions and questions. Brain Behav. Evol.. 46: $124-130$.

Echteler, S.M. (1984) Connections of the auditory midbrain in a teleost ish, Cyprinis carpio. J. Comp. Neurol., 230: 536-551.

Echteler, S.M. (1985) Organization of central auditory pathways in a teleost fish, Cyprinis carpio. J. Comp. Physiol. A, 156:267-280.
Edds, P.L., and A.N. Popper (1990) Comparisons of lagenar and saccular innervation in the goldfish (Carassius auratus), and in the oscar (Astronotus ocellatus). Abstr. Assoc. Res. Otolaryngol., 13: 363.

Edds, P.L., C.E. Cart, and C.A. McCormick (1992) Anti-Zebrin II immunoreactivity reveals Purkinje cell projections to the octaval nuclei of the goldfish, Carassius auratus. Abstr. Assoc. Res. Otolaryngol., 15: 113.

Edds, P.L., J. Presson, and A.N. Popper (1989) A comparison of saccular innervation in the goldfish (Carassius auratus), an otophysan, and the oscar (Astronotus ocellatus), an acanthopterygian. Abstr. Assoc. Res. Otolaryngol., 12: $77-78$.

Fay, R.R., and L. Olsho (1997) Discharge patterns of lagenar and saccular neurons of the goldfish eighth nerve. Displacement sensitivity and directional characteristics. Comp. Biochem. Physiol., 62A: 377-386.

Flock, А. (1971) Sensory transduction in hair cells. In Principles of Receptor Physiology (ed. by W.R. Lowenstein), Handbook of Sensory Physiology, Vol. I, Springer, Berlin, pp. 396-411.

Frishkopf, L.S., and D.J. DeRosier (1983) Mechanical tuning of free-standing ciliary bundles and frequency analysis in the alligator lizard cochlea. Hear. Res., 12: 393-404.

Furukawa, T. (1966) Synaptic interaction at the Mauthner cell of the goldfish. Prog. Brain Res., 21A: $46-70$. 
Furukawa, T., and Y. Ishii (1967) Neurophysiological studies on hearing in goldfish. J. Neurophysiol., 30: 1377-1403.

Highstein, S.M., R. Kitck, J. Carey, and R. Baker (1992) Anatomical organization of the brainstem octavolateralis area of the oyster toadfish, Opsanus tau. J. Comp. Neurol., 319: 501-518.

Hudspeth, A.J. (1985) The cellular basis of hearing: the biophysics of hair cells. Science, 230: 745-752.

Lin, J.-W., D.S. Faber, and M. Wood (1983) Organized projection of the goldfish saccular nerve onto the Mauthner cell lateral dendrite. Brain Res., 274: 319-324.

McCormick, C.A. (1981) Central projections of the lateral line and eighth nerves in the bowfin, Amia calva. J. Comp. Neurol., 197:1-15.

McCormick, C.A. (1983) Central connections of the octavolateralis nerve in the pike cichlid Crenicichla lapidota. Brain Res., 265. $177-185$.

McCormick, C.A. (1992) Evolution of central auditory pathways in anamniotes. In The Evolutionary Biology of Hearing (ed. by D.B. Webster, R.R. Fay, and A.N. Popper), Springer, New York, pp. 323-350.

Meredith, G.E. (1985) The distinctive central utricular projections in the herring. Neurosci. Lett., 55: $191-196$

Meredith, G.E., and A.B. Butler (1983) Organization of eighth nerve afferent projections from individual endorgans of the inner ear in the teleost, Astronotus ocellatus. J. Comp. Neurol. 220: 44-62.

Meredith, G.E., B.L. Roberts, and S. Maslam (1987) Distribution of afferent fibers in the brainstem from end organs in the ear and lateral line in the European eel. J. Comp. Neurol., 265: $507-520$.

Moeng, R., and A.N. Popper (1984) Auditory responses of saccular neurons of the catfish Ictalurus punctatus. J. Comp. Physiol., 155: 615-624.

Moulton, J.M., and R.H. Dixon (1967) Directional hearing in fishes. In Marine Bio-Acoustics II (ed. by W.N. Tavolga), Pergamon Press, New York, pp. 187-228.

Northcutt, R.G. (1980) Central auditory pathways in anamniotic vertebrates. In Comparative Studies of Hearing in Vertebrates (ed. by A:N Popper, and R. R. Fay), Springer, New York, pp. $79-118$.

Platt, C. (1977) Hair cell distribution and orientation in goldfish otolith organs. J. Comp. Neurol., 172: 283-297.

Plart, C. (1983) The peripheral vestibular system in ishes. In Fish Neurobiology, Vol. I (ed. by R.G. Northcutt, and R.E. Davis), Univ, of Michigan Press, Ann Arbor, pp. 89-124.

Platt, C., and A.N. Popper (1981) Fine structure and function of the ear. In Hearing and Sound Communication in Fishes (ed. by W.N. Tavolga, A.N. Popper, and R.R. Fay), Springer, New York, pp. 3-38.
Platt, C., and A.N. Popper (1984) Variations in lenghts of ciliary bundles on hair cells along the macula of the sacculus in two species of teleost fishes. Scan. Electron Microsc., $1915-1924$

Platt, C., and H.Y. Yan (1993) Dramatic differences between fish species for gentamicin pharmacotoxicity. Abstr. Assoc. Res. Otolaryngol., 16: 141.

Popper, A.N. (1977) A scanning electron microscopic study of the sacculus and lagena in the ears of fifteen species of teleost fishes. J. Morphol., 153: 397-418.

Popper, A.N., and S. Coombs (1982) The morphology and evolution of the ear in actinopterygian fishes. Amer. Zool., 22: 311-328.

Popper, A.N., and R.R. Fay (1993) Sound detection and processing by fish: critical review and major research questions. Brain Behav. Evol., 41: $14-38$.

Popper, A.N., and C. Platt (1993) Inner ear and lateral line of bony fishes. In The Physiology of Fish (ed. by D.H. Evans), CRC Press, Boca Raton, Florida, pp. 99-136.

Popper, A.N., and W.M. Saidel (1990) Variations in receptor cell innervation in the saccule of a teleost fish ear. Hear. Res., 46: 211-227.

Popper, A.N., and W.N. Tavolga (1981) Structure and function of the ear of the marine catfish, Arius felis. J. Comp. Physiol., 144: 27-34.

Popper, A.N., C. Platt, and W.M. Saidel (1982) Acoustic function in the fish ear. Trends Neurosci., $5: 276-280$.

Popper, A.N., W.M. Saidel, and J.S.Y. Chang (1993) Two types of sensory hair cell in the saccule of a teleost fish. Hear. Res., 66 $211-216$.

Presson, J.C., P.L. Edds, and A.N. Popper (1992) Central-peripheral and rostral-caudal organization of the innervation of the saccule in a cichlid fish. Brain Behav. Evol., 39: 196-207.

Retzius, G. (1881) Das Gehörorgan der Wirbelthiere. Vol. I. Samson and Wallin, Stockholm

Saidel, W.M. P.J. Lanford, H.A. Yan, and A.N Popper (1995) Hair cell heterogeneity in the goldfish saccule. Brain Behav. Evol., in press.

Saidel, W.M., A.N. Popper, and J.S. Chang (1990a) Spatial and morphological differentiation of trigger zones in afferent fibers to the teleost utricle. J. Comp. Neurol., 302: 629-642.

Saidel, W.M., J.C. Presson, and J.S. Chang (1990b) S-100 immunoreactivity identifies a subset of hair cells in the utricle and saccule of a fish. Hear. Res., 47: 139-146.

Saunders, J.C., and S.P. Dear (1983) Comparative morphology of stereocilia. In Hearing and Other Senses: - Presentations in Honor of E.G. Wever (ed. by R.R. Fay, and G. Gourevitch), Amphora Press, Groton, Connecticutt.

Schellart, N.A.M., and A.N. Popper (1992) Functional aspects of the evolution of the auditory system of actinopterygian fish. In Comparative Evolutionary Biology of Hearing (ed. by D.B. Webster, R.R. Fay, and A.N. Popper), Springer, New York, pp. 295-322.
Schnitzlein, H.N., and J.R. Faucette (1969) General morphology of the fish cerebellum. In Neurobiology of Cerebellar Evolution and Development (ed. by R. Llinas), AMA, Chicago, pp. 77-106.

Sento, S., and T. Furukawa (1987) Intra-axonal labeling of saccular afferents in the goldfish Carassius auratus: correlations between morphological and physiological characteristics. J. Comp. Neurol., 258: 352-367.

Steinacker, A., and A. Romero (1992) Voltagegated potassium current and resonance in the toadfish saccular hair cells. Brain Res., 574: 229-236.

Sugihara, I., and T. Furukawa (1989) Morphological and functional aspects of two different types of hair cells in the goldfish sacculus. J. Neurophysiol., 62: 1330-1343.

Szabo, T., M. Ravaille, and S. Libouban (1978) Club endings of primary afferent fibres identified by anterograde horseradish peroxidase labelling. An EM study. Neurosci. Lett., 9: $7-15$.

von Frisch, K. (1938) Über die Bedeutung des Sacculus und der Lagena für den Gehörsinn der Fische. Z. Vergl. Physiol., 25: 703-747.

Wegner, N. (1982) A qualitative and quantitative study of a sensory epithelium of the inner ear of a fish (Colisa labiosa; Anabantidae). Acta Zool., 63: 133-146.

Wersäll, J. (1960) Vestibular receptor cells in fish and mammals. Acta Otolaryngol., Stockh. Suppl., 163:25-29.

Yan, H.Y., W.M. Saidel, J. Chang, J.C. Presson, and A.N. Popper (1991) Sensory hair cells of the fish ear: evidence of multiple types based on ototoxicity sensitivity. Proc. Roy. Soc. Ser. B., 245: $133-138$

Zottoli, S.J. (1976) Fishing behavior of common grackles. Auk, 93: 640-642.

Zottoli, S.J. (1977) Correlation of the startle reflex and Mauthner cell auditory responses in the unrestrained goldfish. J. Exp. Biol., 66 : $243-254$.

Zottoli, S.J. (1978) Comparative morphology of the Mauthner cell in fish and amphibians. In Neurobiology of the Mauthner Cell (ed. by $D$. Faber, and H. Kom), Raven Press, New York pp. $13-45$.

Zottoli, S.J. (1981) Electrophysiological and morphological characterization of the winter flounder Mauthner cell. J. Comp. Physiol. A, 143 : $541-553$.

Zottoli, S.J., and D.S. Faber (1979) Properties and distribution of anterior VIIIth nerve excitatory inputs to the goldfish Mauthner cell. Brain Res., 174: 319-323.

Zottoli, S.J., and C. van Horne (1983) Posterior lateral line afferent and efferent pathways within the central nervous system of the goldfish with special reference to the Mauthner cell. J. Comp. Neurol., 219: 110-111. 